\title{
HAK ASASI PEREMPUAN DALAM HUKUM KELUARGA BERBASIS AL -QUR'AN
}

\author{
Women's Rights In Family Law Based on Qur'an
}

$$
\text { حقوق المرأة في قانون الأسرة على أساس القرآن }
$$

\author{
Ahmad Chalabi \\ Kantor Urusan Agama Kalideres Kementerian Agama Jakarta Barat, Indonesia \\ ahmadchalabi578@gmail.com
}

\begin{abstract}
Abstrak
Kesimpulan dari artikel ini bahwa bahwa Hak Asasi Perempuan dalam hukum keluarga perspektif Al-Qur'an adalah hak dasar yang melekat pada diri perempuan sebagai anugerah dari Tuhan terkait norma dan hukum yang melindungi perempuan sebagai seorang individu, makhluk sosial dan dimensi spritual. Hak perempuan secara individu dalam hukum keluarga adalah hak kesempatan meraih pendidikan dan berprestasi, hak terkait perkawinan dan hak khulu dan waris. Sedangkan hak perempuan sebagai mahkluk sosial adalah, hak perempuan untuk memiliki kesempatan berkpirah secara seimbang di ruang domestik dan publik, yaitu: Hak untuk bekerja, hak menjadi pemimpin, hak berwirausaha, hak keamanan dan kenyamanan di tempat bekerja dan media sosial, termasuk hak mendapatkan lingkungan yang sehat. Adapun hak perempuan sebagai dimensi spritual, perempuan juga memiliki hak beribadah, sesuai ketentuan agama dan dengan keinginan dan kemampuan yang dimilikinya, tidak ada yang dapat merampas hak perempuan utnuk beribadah
\end{abstract}

Kata Kunci : Perempuan, Hak Asasi, Hukum Keluarga, Al-Qur'an

\begin{abstract}
The conclusion of this article is that the human right of women in law. The perspective of the koran is a basic right inheren in women as a gift from God related to norm s and laws that protect women as individual sosial beings and the spritual dimension. Individual women's right in family law are the right to the right to the opportunity to gain education and achievement, right related to marriege and khulu right and enheritance right. While women's right as social beings is the right of women to have the opportunity to take part in a balanced manner in the domestic and public sphere, namely the right to work the right to become the leader of entrepreneurial right, security rights, fan comfort in the workplace and social media including getting a healty environment. As well as women's right as a spritual dimension women also have the right as a spritual dimension women also have the right to worship according to religios provisions and with the dosire and ability no one can deprive women of their right to worship.
\end{abstract}

Keywords : Woman, Rights, Family Law, Qur'an

$$
\begin{aligned}
& \text { الملخص } \\
& \text { وخلاصة هذا المقال أن حقوق الإنسان للمرأة في قانون الأسرة من منظور القرآن هي حقوق أساسية متأصلة في المرأة باعتبارها هبة من }
\end{aligned}
$$

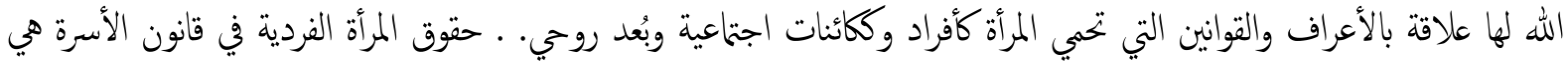

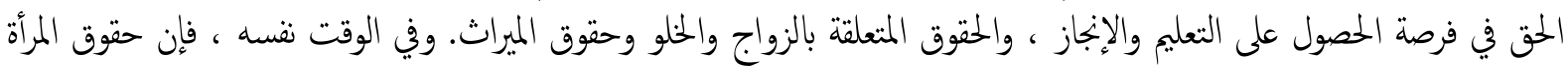




$$
\begin{aligned}
& \text { ككائنات اجتاعية هي حقوق المرأة في الحصول على فرص متساوية لملمرستها في الجمالين المنزلي والعام ، وهي: الحق في العمل ، والحق }
\end{aligned}
$$

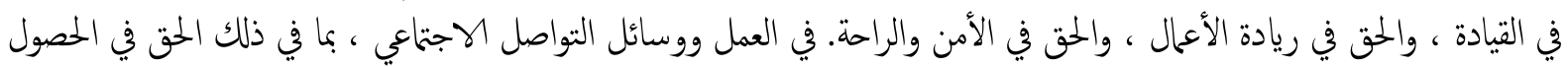

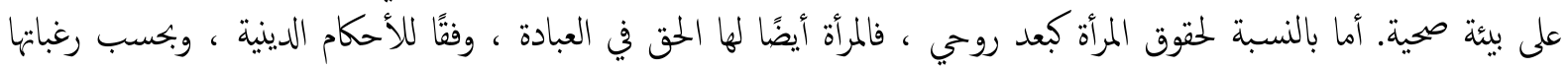

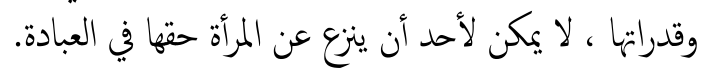

$$
\begin{aligned}
& \text { الكلمات المفتاحية: المرأة ، حقوق الإنسان ، قانون الأسرة ، القرآن }
\end{aligned}
$$

\section{Pendahuluan}

Hingga saat ini diskursus tentang hak-hak asasi perempuan telah muncul sebagai suatu masalah yang sangat penting diperbincangkan di mana-mana, tidak hanya di Indonesia tapi diseluruh dunia. Isu-isu tentang perempuan merupakan kajian yang banyak dilakukan oleh para akademisi, khususnya dari kalangan pemerhati dan pengakaji perempuan itu sendiri, bahkan bermacam-macam teori telah dimunculkan sehingga melahirkan keberagamaan nilai, ide atau perspektif yang tujuannya diarahkan untuk mencapai formasi yang tepat sasaran dalam meletakkan persamaan hak antara laki-laki dan perempuan. Berbagai macam upaya untuk melindungi hak asasi perempuan dan membebaskan mereka dari pelanggaran hak asasi manusia telah lama diperjuangkan melalui berbagai cara. Hingga akhirnya, ide tentang hak asasi perempuan ini memperoleh respon dari Perserikatan Bangsa Bangsa (PBB) dalam bentuk pembentukan sebuah konvensi yang bernama Konvensi Penghapusan Segala Bentuk Diskriminasi Terhadap Perempuan atau Convention on the Elimination of All Forms of Discrimination Against Women $(C E D A W){ }^{1}$

Penghapusan segala bentuk diskriminasi terhadap perempuan (CEDAW), yang ditandatangani pada 1979 dalam konvensi yang diadakan Komisi Kedudukan PBB ini dapat dirangkum menjadi 5 poin utama terkait hak asasi perempuan, yaitu: hak dalam ketenagakerjaan, pendidikan, kesehatan, hak dalam kehidupan keluarga, dan hak dalam kehidupan publik dan politik. ${ }^{2}$ Upaya ini mendapat apresiasi positif dan menjadi landasan bagi pemenuhan hak-hak perempuan dalam kelima poin tersebut. Namun, sebagai produk pemikiran $C E D A W$ tidak jaran mendapat kritik tidak hanya pada tataran konsep tapi juga pada implementasinya. Penolakan terhadap CEDAW karena isinya dianggap terlalu mempokuskan pada aspeksosial-budaya dan politik dalam melihat persoalan perlakuan diskriminatif terhadap hak asasi perempuan. Selain itu, CEDAW dinilai juga terlalu memperluas aplikasi HAM dalam ruang privat perempuan, sehingga ruang publik dan privat dibahas dengan sedemikian nyata hingga keduannya menjadi konsumsi publik.

Memang, CEDAW tidak hanya berisi tentang hak-hak perempuan di wilayah domestik, ia juga menjamin hak-hak perempuan di wilayah publik. Tapi,

${ }^{1}$ Konvensi Penghapusan Segala Bentuk Diskriminasi terhadap Perempuan (CEDAW) adalah sebuah kesepakatan bersama secara internasional yang ditetapkan oleh Perserikatan Bangsa-Bangsa (PBB) pada tahun 1979. Konvensi ini dianggap sebagai perjanjian internasional untuk hak asasi perempuan. Konvensi ini mulai berlaku sejak ditetapkannya pada tanggal 3 September 1981 dan sampai saat ini telah ditandatangani oleh 189 negara. Lihat UN Women, "Declaration, Reservation and Objections to CEDAW," dalam https://www.unwomen.org/en. Diakses pada 16 April 2020.

${ }^{2}$ Kementerian Pemberdayaan Pemberdayaan Perempuan dan Perlindugan Anak, "5 Hak-Hak Utama Perempuan"

81 | al-\$urhan: Kajian Ilmu dan Pengembangan Budaya Al-Qur'an, Vol. 20, No. 1, Juni 2020: 80-97. 
persoalannya adalah seberapa efektif $C E D A W$ dalam melindungi hak asasi perempuan? Di Indonesia sendiri berbagai kenyataan dilapangan menunjukan masih terjadinya pelanggaran-pelanggaran hak-hak perempuan, dan belum terwujudnya keadilan terhadap hak-hak perempuan.

Selain tidak efektifnya penerapan $C E D A W$, ada banyak aspek lain juga yang perlu mendapat perhatian, salah satunya adalah persoalan hak perempuan dalam keluarga. Dalam $C E D A W$ pasal 5 menekankan untuk menghilangkan segalah bentuk perlakuan diskriminatif pada wilayah privat, yaitu keluarga yang menurut CEDAW merupakan tempat yang paling utama dan sering adanya tindakan ketidakadilan terhadap hak asasi perempuan. ${ }^{3}$ Bagi kalangan aktifis feminisme, pasal ini menjadi dasar legitimisi bolehnya perempuan menjadi pemimpin dalam rumah tangga. ${ }^{4}$ Pemikiran feminis ini tentu saja bertentangan dengan Al-Qur'an surah An-Nisa ayat 34 yang mengharuskan laki-laki sebagai pemimpin dalam rumah tangga.

Pada dasarnya Islam sangat memuliakan seorang perempuan. Jauh sebelum para aktivis feminis memperjuangkan hak-hak perempuan dan pembentukan Konvensi Penghapusan Segala Bentuk Diskriminasi Terhadap Perempuan (CEDAW). Al-Qur'an sudah menawarkan sebuah solusi terhadap pemenuhan hak asasi perempuan yang digambarkan dalam berbagai surat dan ayat. Atas dasar pemikiran tersebut, penulis menilai perlunya suatu upaya melakukan kajian serius terhadap hakhak perempuan dalam hukum keluarga berbasis al-Quran. Oleh karena itu, judul yang penulis angkat adalah : "Hak-Hak Asasi Perempuan dalam Hukum Keluarga Berbasis Al-Qur'an”. Harapannya, dari hasil penelitian ini dapat memberikan ulasan yang komprehensif dan jelas tentang hak asasi perempuan dalam hukum keluarga yang berbasis al-Quran.

\section{Pengertiah Hak Asasi Perempuan}

Dalam bahasa Indonesia, istilah hak memiliki berbagai macam makna. Poerwadarminta menyebutkan bahwa kata hak memiliki makna: 1. (yang) benar; (yang) sungguh ada; kebenaran; 2) Kekuasaan yang benar-atas sesuatu atau untuk menuntut sesuatu; 3) Kekuasaan untuk berbuat sesuatu

3 Bunyi dari Pasal 5 tersebut adalah sebagai berikut: "States Parties shall take all appropriate measures: (a) To modify the social and cultural patterns of conduct of men and women, with a view to achieving the elimination of prejudices and customary and all other practices which are based on the idea of the inferiority or the superiority of either of the sexes or on stereotyped roles for men and women; (b) To ensure that family education includes a proper understanding of maternity as a social function and the recognition of the common responsibility of men and women in the upbringing and development of their children, it being understood that the interest of the children is the primordial consideration in all cases." Lihat Partners for Law in Development (PLD), CEDAW; Mengembalikan Hak-hak Perempuan, di terj. dan disunting oleh: Achie S. Luhulima, Jakarta: Juni, 2007, 38.

${ }^{4}$ Salah satu usaha yang dilakukan oleh aktifis feminis dalam upaya pemenuhan hak asasi perempuan adalah dengan membuat Rancangan Undang-Undang (RUU) Ketahanan Keluarga yang diajukan untuk dibahas oleh DPR RI pada Februari 2020. Isi dari pasal tersebut berbunyi: "Kewajiban istri sebagaimana dimaksud dalam ayat 1, antara lain: (a) wajib mengatur urusan rumah tangga sebaik-baiknya; (b) menjaga keutuhan keluarga; serta (c) memperlakukan suami dan anak secara baik, serta memenuhi hah-hak suami dan anak sesuai norma agama, etika sosial, dan ketentuan peraturan perundang-undangan. Pada dasanya pasala ini memberikan peluang yang luas bagi perempuan untuk menjadi pemimpin dalam rumah tangga. Lihat dpr.go.id, "Kritik terhadap Pasal 25 RUU tentang Ketahanan Keluarga dari Perspektif Gender," dalam http://berkas.dpr.go.id/. Diakses pada 26 April 2020. 


\section{Ahmad Chalabi}

(karenatelah ditentukan olehaturan, undang-undangdan sebagainya; 4) Kewenangan; dan 5) Milik; kepunyaan. ${ }^{5}$

Pada dasarnya, kata hak berasal dari bahasa Arab yaitu haq yang diambil dari akar kata haqqa,yahiqqu, haqqan yang artinya benar, nyata, pasti, tetap, dan wajib. Apabila dikatakan yahiqqu 'alaika 'an tafala kaza itu artinya kamu wajib melakukan seperti ini. ${ }^{6}$ Dengan demikian, haqa dalah kewenangan atau kewajiban untuk melakukan atau tidak melakukan sesuatu.

Secara pengertian perempuan sendiri secara etimologis berasal dari kata empu yang berarti "tuan", orang yang mahir atau berkuasa, kepala, hulu, yang paling besar. ${ }^{7}$ Namun dalam bukunya Zaitunah Subhan perempuan berasal dari kata empu yang artinya dihargai. Lebih lanjut Zaitunah menjelaskan pergeseran istilah dari wanita ke perempuan. Kata wanita dianggap berasal dari bahasa sanskerta, dengan dasar kata wan yang berarti nafsu, sehingga kata wanita mempunyai arti yang dinafsui atau merupakan objek jadi subjek. Tetapi dalam bahasa Inggris wan ditulis dengan kata want, atau men dalam bahasa Belanda, wun dan schen dalam bahasa-Jerman. Kata tersebut mempunyai arti like, wish, desire, aim, kata want dalam bahasa Inggris bentuk lampaunya wanted. Jadi, wanita adalah who is being wanted (seseorang yang dibutuhkan) yaitu seseorang yang diinginkan. ${ }^{8}$ Sementara itu feminisme perempuan mengatakan, bahwa perempuan merupakan istilah untuk konstruki sosial yang identitasnya ditetapkan dan dikonstruksi melalui penggambaran. ${ }^{9}$ Dari sini dapat difahami bahwa kata perempuan pada dasarnya merupakan istilah untuk menyatakan kelompok atau jenis dan membedakan dengan jenis lainnya.

Berdasarkan uraian tentang pengertian hak dan perempuan di atas, maka yang dimaksudkan dengan hak asasi perempuan adalah kewenangan atau kewajiban yang dimiliki perempuan untuk melakukan atau tidak melakukan sesuatu sehingga tidak hanya mengandung unsur perlindungan tetapi juga kehendak yang oleh hukum mendapat jaminan untuk memenuhinya. Sehingga secara garis besar, hak asasi perempuan adalah hak yang dimiliki oleh seorang perempuan, baik karena ia seorang manusia maupun sebagai seorang perempuan. Hak ini ada mengingat rentannya posisi perempuan dalam proses berkeluarga, bermasyarakat, budaya, ekonomi, sosial yang dimaksudkan untuk memberikan perlindungan. Setiap perempuan memiliki hak ini walaupun sejauh mana hak-hak tersebut dipenuhi dalam praktik, sangat bervariasi dari negara ke negara. Hak asasi perempuan bertujuan menjamin martabat setiap perempuan. $^{10}$

\footnotetext{
${ }^{5}$ W.J.S. Poerwadarminta, Kamus Umum Bahasa Indonesia (Jakarta: Balai Pustaka, 1982), 339.

6 J. Milton (ed.) Hans Wehr:A Dictionary of Modern Written Arabic (Weibaden: Otto Harrassowitz, 1979), 191-192.

${ }^{7}$ Mansour Fakih, Analisis Gender dan Transformasi Sosial, Cet. 9 (Yogyakarta: Pustaka Pelajar, 2005), 135 .

${ }^{8}$ Zaitunah Subhan, Qodrat Perempuan Taqdir Atau Mitos (Yogyakarta: Pustaka Pesantren, 2004), 1.

${ }^{9}$ Syafiq Hasyim, Pengantar Feminisme dan Fundamentalisme Islam, Cet. I (Yogyakarta : LkiS, 2005 ), 5 .

1o Kelompok Kerja Convention Watch, Hak Azasi Perempuan: Instrumen Hukum untuk Mewujudkan Keadilan Gender (Jakarta: Yayasan Obor Indonesia, 2007), 62.
}

83 | al-هurhan: Kajian Ilmu dan Pengembangan Budaya Al-Qur'an, Vol. 20, No. 1, Juni 2020: 80-97. 


\section{Hak Asasi Perempuan dalam Rumusan PBB}

Hak asasi perempuan dalam rumusan PBB yang dimaksud disini adalah Hak asasi perempuan yang dirumuskan oleh PBB dalam CEDAW. CEDAW sendiri adalah salah satu konvensi utama tingkat internasional yang membela hak-hak perempuan sebagaimana tercantum dalam resolusi Mahkamah Umum No. 34/180 tanggal 18 Desember 1979. CEDAW disusun untuk diadopsi dan diratifikasi oleh negara-negara anggota PBB. CEDAW memuat 30 pasal dan secara formal dan legal dinyatakan sebagai dokumen internasional (entry into force) tanggal 3 September $1981 .^{11}$

Dalam mukadimah CEDAW dinyatakan asas-asas konvensi yang merupakan prinsip dasar menjadi acuan berpikir dalam mengabil keputusan penting dalam merumuskan $C E D A W$. Adapun asas-asas tersebut antara lain:

1. Keyakinan atas hak asasi manusia, atas martabat dan nilai pribadi manusia, dan atas persamaan hak antara laki-laki dan perempuan.

2. Semua manusia dilahirkan bebas dan sama dalam martabat dan hak, dan bahwa setiap orang berhak atas semua hak dan kebebasan yang dimuat di dalamnya, tanpa perbedaan apapun, termasuk perbedaan jenis kelamin.

3. Adanya jaminan hak yang sama laki-laki dan perempuan untuk menikmati semua hak ekonomi, sosial, budaya, sipil dan politik.

4. Diskriminasi terhadap perempuan melanggar asas-asas persamaan hak dan penghargaan terhadap martabat manusia menghambat partisipasi perempuan dalam kehidupan politik, sosial, ekonomi dan budaya; menghambat pertumbuhan kemakmuran masyarakat dan keluarga; menambah sukarnya perkembangan sepenuhnya dari potensi perempuan dalam pengabdiannya pada negara dan kemanusiaan.

5. Sumbangan besar perempuan pada kesejahteraan kelauarga dan pembangunan masyarakat, peranan kedua rangtua dalam keluarga dan dalam membesarkan anak-anak, bahwa peranan perempuan dalam memperoleh keturunan hendaknya jangan menjadi dasar diskriminasi, akan tetapi bahwa membesarkan anak-anak mewajibkan berbagai tanggung jawab antara laki laki dan perempuan dan masyarakat secara keseluruhan.

6. Diperlukan perubahan pada peranan tradisioanal laki-laki maupun perempuan dalam masyarakat dan dalam keluarga, untuk mencapai kesetaraan sepenuhnya antara laki-laki dan perempuan.

7. Bertekad untuk melaksanakan asas-asas yang tercantum dalam Deklarasi Mengenai Penghapusan Diskriminasi Terhadap Perempuan, dan untuk maksud itu melaksanakan langkah tindak yang diperlukan untuk menghapus diskriminasi dalam segala bentuk dan manifestasinya. ${ }^{12}$

CEDAW menekankan pada kesetaraan (equality) dan keadilan (equity) lakilaki dan perempuan, yaitu persamaan hak dan kesempatan serta perlakuan disegala bidang dan kegiatan. Konvensi ini mengakui adanya:

1. Perbedaan biologis atau kodrati antara laki-laki dan perempuan.

2. Perbedaan perlakuan perempuan berbasis gender mengakibatkan kerugian pada perempuan, berupa subordinasi kedudukan dalam keluarga dan masyarakat,

\footnotetext{
${ }^{11}$ Achie Sudiarti Luhulima, CEDAW: Menegakkan Hak Asasi Perempuan (Jakarta: Yayasan Pustaka Obor Indonesia, 2014), 61.

${ }^{12}$ Vicky J. Semler et.al,. Hak Asasi Perempuan, Sebuah Panduan Konvensi-konvensi Utama PBB tentang Hak Asasi \{Perempuan, terj. Embun (Jakarta: Yayasan Jurnal Perempuan, 2001), 16.
} 


\section{Ahmad Chalabi}

maupun pembatasan kempuan dalam memanfaatkan peluang yang dapat berupa peluang tumbuh kembang secara opimal, menyeluruh dan terpadu sejalan dengan potensi yang dimiliki.

3. Perbedaan kondisi dan posisi antara laki-laki dan perempuan dimana perempuan menempati posisi yang lebih lemah karena mengalami diskriminasi. ${ }^{13}$

$C E D A W$ terdiri atas tiga puluh pasal mencakup materi berbeda. Selain berisi tentang diskriminasi perempuan, di dalamnya terdapat hak anak, sosialpolitik, sosial budaya, ekonomi, dan lainlain. Secara umumisi CEDAW terdiri atas: (a)-pasal 116 mendiskusikan tentang Prinsipprinsip dalam Konvensi, ${ }^{14}$ (b) Pasal membahas tentang hak-sipil dan politik perempuan, (c) Pasal 1014 menetapkan tentang hak perekonomian,social dan budaya, (d) pasal 16 membincang tentang Hak perempuan setelah menikah (menjadi istri) berikut hak terhadap anak akibat perkawinan, (e) Pasal 22 tentang Komiteo CEDAW dan mekanisme Laporan pelaksanaan konvensi, (f) opasal 30 adalah tentang pemberlakuan Konvensi, ratifikasi adopsi serta reservasi Konvensi,diantara pasal yang menegaskan mengenai hak perempuan dalam CEDAW adalah: ${ }^{15}$

Persamaan wanita dengan pria dalam perkawinan, yaitu akan diberikan hak untuk mengadakan pergerakan dan memilih tempat kediaman;

1. Persamaan wanita dengan pria akan dijamin terhadap hak dan tanggung jawab dalam hubungan kekeluargaan dan semua urusan mengenai perkawinan, khususnya beberapa hak wanita bersama dengan pria akan dijamin dibidang perkawinan;

2. Dalam pasal 16 huruf (a) disebutkan hak yang sama antara pria dan wanita untuk melakukan ikatan perkawinan;

3. Dalam pasal 16 huruf (b) Hakhak yang sama untuk memilih dengan bebas pasangan hidupnya dan untuk masuk ke dalam ikatan perkawinan hanya dengan persetujuan bebas dan sepenuhnya;

4. Dalam pasal 16 huruf (c) mensyaratkan Hakhak dan tanggung jawab yang sama selama perkawinan dan pada pemutusan perkawinan;

5. Pasal 16 ayat 1 huruf (d) mengakui hak pribadi yang sama sebagai suamiistri termasuk hak memilih nama, keluarga, profesi dan jabatan;

\footnotetext{
${ }^{13}$ Ihromi Omas, et.al,. Penghapusan Diskriminasi Terhadap Perempuan, Bandung: PT Alumni, 2006, hal. 389

${ }_{14}$ Prinsip NonDiskriminatif menjadi pokok dari seluruh pasal konvensi secara tegas menyebutkan apa yang disebut diskriminasi terhadap perempuan, yaitu setiap perbedaan, pengucilan, atau pembatasan yang dibuat atas dasar jenis kelamin, yang bertujuan mengurangi atau menghapuskan pengakuan, penikmatan, atau penggunaan hakhak asasi manusia dan kebebasankebebasan pokok di bidang politik, ekonomi, sosial, budaya, sipil, atau apapun lainnya oleh kaum perempuan, terlepas dari status perkawinan mereka atas dasar persamaan antara lakilaki dan perempuan. Prinsip persamaan (keadilan substantif) dalam Konvensi Perempuan merupakan sebuah pendekatan yang mendasarkan pada hasil akhir dari sebuah proses, yaitu keadilan. Dalam mencapai tujuan akhir tersebut, prosesnya tidak harus sama antara lakilaki dan perempuan, mengingat situasi dan kebutuhan antara lakilaki dan perempuan terkadang berbeda, namun perbedaan tersebut pada satu sisi juga akibat adanya diskriminasi terhadap perempuan yang berlangsung sejak lama. Lihat Sriwiyanti Eddiyono, Bahan Bacaan Kursus HAM dan Materi Konvensi CEDAW, Jakarta: Lembaga Pengembangan dan Advokasi Masyarakat, 2005, hlm. 89 .

${ }^{15}$ Kelompok Kerja Convention Watch, Hak Azasi Perempuan: Instrumen Hukum untuk Mewujudkan Keadilan Gender, Jakarta: Yayasan Obor Indonesia, 2007, hal. 62
}

85 | at-\$urhan: Kajian Ilmu dan Pengembangan Budaya Al-Qur'an, Vol. 20, No. 1, Juni 2020: 80-97. 
6. Pasal 16 ayat 1 huruf (f) mensyaratkan hak yang sama untuk kedua suami dan istri berkaitan dengan-benda;

7. Pasal 16 ayat 2 melarang pertunangan dan perkawinan seorang anak (nikah dini);

8. Hak sama untuk suami istri berhubungan dengan pemilikan atas perolehan pengelolaan harta benda. ${ }^{16}$

\section{Hak Asasi Perempuan Dalam Hukum Keluarga dalam Perspektif Al-Qur'an 1. Hak Menikah dengan Keinginan Sendiri}

Kasus perjodohan oleh orang tua kepada anak perempuannya masih sering dijumpai dalam kehidupan masyarakat Indonesia, bahkan di dunia. ${ }^{17}$ Beberapa dijumpai kasus nikah paksa yang dilakukan oleh orang tua terhadapanak perempuannya. Tak jarang, praktek nikah paksa yang dilakukan oleh oknum orang tua - yang oleh orang tua bertujuan membahagiakan anak perempuannya justru berakhir dengan penyiksaan fisik maupun batin kepada anak perempuannya. Efeknya, umur pernikahan tidak berjalan lama.

Jika sudah demikian, ujung-ujungnya yang dirugikan adalah kaum perempuan. Seorang perempuan kerap kali tidak bisa berbuat apa-apa ketika dihadapkan pada persoalan seperti ini. Di satu sisi -dengan mematuhi perintah orang tuanya menerima perjodohan tersebut-ia beranggapan bahwa hal itu adalah sebuah bentuk bakti kepada orang tua. Namun di sisi lain, sebenarnya perempuan itu menjerit, karena merasa haknya telah dirampas dengan semena-mena oleh keegoisan orang tua. Beberapa perempuan korban nikah paksa yang pernah dijumpai penulis tidak dapatberbuat banyakdan pasrah Dalam posisi semacam ini, merekaselalu dihantui perasaan sebagai anak yang durhakabila tidak mematuhi keinginan orang tuanya.

Hak memilih suami bagi seorang perempuan dalam Islam tidak dibedakan antara laki-laki dan perempuan. Persamaan laki-laki dan perempuan dalam masalah ini dapat ditinjau dari persamaan dalam hak dan kewajiban dalam agama. Kedudukan seorang perempuan tidak lebih rendah dari laki-laki, baik dalam akal, kecakapan, maupun kewajiban-kewajiban lain yang bersifat syar ${ }^{\text {ei }}$. Keduanya mempunyai hak dan kewajiban yang sama. Persamaan ini banyak ditunjukkan oleh ayat-ayat berikut ini: ${ }^{18}$

\footnotetext{
${ }^{16}$ Sriwiyanti Eddiyono, Bahan Bacaan Kursus HAM dan Materi Konvensi CEDAW, 90

${ }^{17}$ Para pakar memperkirakan setiap tahun korban nikah paksa di Inggris berkisar antara 5.000 sampai 8.000 orang. Sebagian besar perempuan yang dipaksa menikah berusia di bawah 21 tahun dan sebagian berusia di bawah 15 tahun. Sebagian keluarga korban berasal dari Pakistan, Bangladesh dan India. Tetapi ada sejumlah kasus yang dilaporkan terjadi pada komunitas Afrika, Amerika Latin dan juga Eropa Timur. (http://www.bbc.co.uk/indonesia/dunia/2020/06/120608 forced marriages.shtml). Gadis cilik asal Yaman berusia 8 tahun tewas akibat luka dalam saat malam pertama pernikahannya. Si gadis dinikahkan paksa dengan pria berumur lebih dari 5 kali lipat usianya. Seperti diberitakan News.com.au, Selasa (10/9/2020) si gadis menderita sobek pada alat kelamin dan pendarahan hebat. Dia tewas di Kota Hardh Provinsi Hajjah di barat laut Yaman. (http://news.liputan6.com/read/688379/tragis-gadis-8-tahun-korban-nikah-paksa-tewas-saat-malampertama).

${ }^{18}$ Dalal Kadzim 'Ubayd, Mafhum Hurriyat al-Mar'ah fi Dlaw al-Fikr al-Tarbawial-Islami (Beirut: Kitab-Nashirun, 2011), 111.
} 


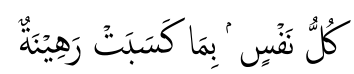

Tiap-tiap individu (baik laki-laki maupun perempuan) bertanggung jawab atas apa yang telah diperbuatnya. (Al-Muddatstsir/74:38)

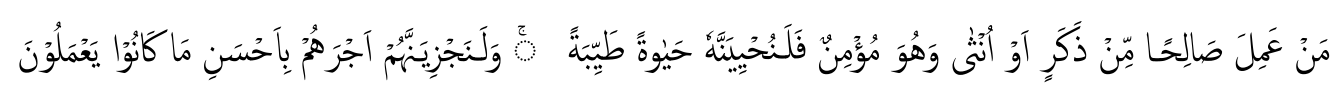

Barangsiapa yang mengerjakan amal saleh, baik laki-lakimaupun perempuan dalam keadaan beriman, makasesungguhnya akan Kami berikan kepadanya kehidupan yang baik dan sesungguhnya akan Kami beri balasan kepada mereka dengan pahala yang lebih baik dari apa yang telah mereka kerjakan." (Al-Nahl/16: 97)

Ayat-ayat di atas menegaskan persamaan antara laki-laki dan perempuan dalam mendapatkan pahala amal saleh. Bila dalam amal aleh kaum perempuan mendapatkan hak yang sama dalam pahala, maka tentunya dalam memilih suami pun mereka mempunyai hak yang sama seperti halnya kaum laki-laki. Mempunyai seorang suami (suami yang saleh tentunya) merupakansalah satu cara bagi kaum perempuan untuk tetapdapat berbakti kepada Allah.

Asghar Ali Engineer berpendapat bahwa di dalam Al-Qur'an perempuan setara dengan laki-laki dalam kemampuan mental dan moralnya, sehingga masing-masing memiliki hak independen yang sama dalam menentukan pasangannya. ${ }^{19}$ Dalam konteks inidia mendasarkan pada ayat al-Quar'an, surat al-Ahzab ayat 35 sebagai berikut:

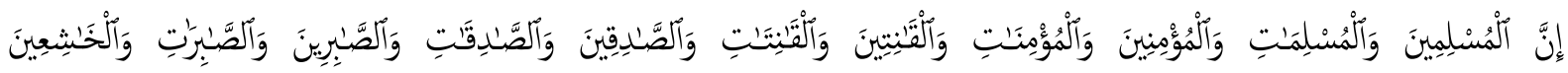

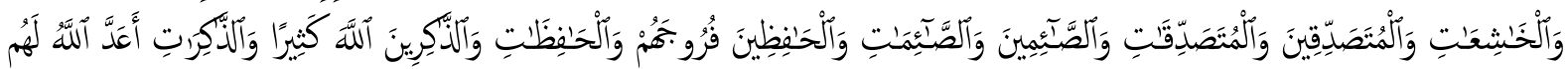

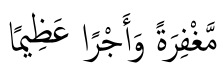

Sesungguhnya kaum lelaki dan wanita yang tunduk, percaya pada Allah dan RasulNya, melakukan ketaatan, jujur dalam perkataan, perbuatan dan niat, tabah dalam menghadapi cobaan dalam berjuang di jalan Allah, merendahkan diri, menyedekahkansebagian harta bagi orang yang membutuhkan, melakukan puasa wajib dan sunnah, menjaga kemaluan dari hal-hal yang dilarang, serta berzikir pada Allah dengan hati dan lisan, niscaya Allah akan memberikan pengampunan bagi segala dosa dan pahala yang besar atas perbuatan baik mereka. (Al-Ahzab/33:35)

Dari ayat di atas menurut pendapat Asghar, bahwa kesetaraan laki-laki dan perempuan yang disebutkan Al-Qur'an meliputi pula kesetaraan laki-laki dan perempuan dalam kontrak perkawinan. Seorang perempuan sebagai pihak yang sederajat dengan laki-laki, yang dapat menetapkan syarat-syarat yang diinginkannya sebagaimana juga laki-laki. Laki-laki tidak lebih tinggi kedudukannya dalam hal ini. ${ }^{20}$ Hal ini sangat relevan dengan ke-tentuan yang terdapat dalam Kompilasi Hukum Islam yaitu: "Hak dan kedudukan isteri adalah seimbang

\footnotetext{
${ }^{19}$ Asghar Ali Engineer, Hak-hak Perempaun dalam Islam, terj. Farid Wajidi (Bandung, LSPPA, 1994), 137.

${ }^{20}$ Asghar Ali Engineer, Hak-hak Perempaun dalam Islam, 138.

87 | al-\$urhan: Kajian Ilmu dan Pengembangan Budaya Al-Qur'an, Vol. 20, No. 1, Juni 2020: 80-97.
} 
dengan hak dan kedudukan suami dalam kehidupan rumah tangga dan pergaulan hidup bersama dalam masyarakat. Masing-masing pihak berhak untuk melakukan perbuatan hukum." ${ }^{21}$

\section{Hak Menikah di Usia Matang}

Al-Qur'an telah memberikan isyarat bahwa seseorang yang akan melangsungkan pernikahan, baik laki-laki maupun perempuan haruslah merupakan orang yang sudah layak dan dewasa sehingga bisa mengatur dan menjalani kehidupan rumah tangganya dengan baik. Dan dengan kedewasaan itu pulalah pasangan suami istri akan mampu menunaikan hak dan kewajibannya secara timbal balik. Dalam surat al-Nisa' ayat 6 disebutkan:

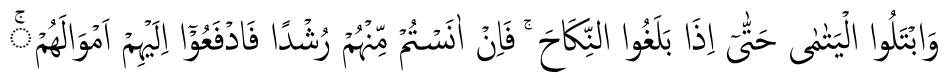

Dan ujilah anak-anak yatim itu sampai mereka cukup umur untuk menikah. Kemudian jika menurut pendapatmu mereka telah cerdas, maka serahkanlah kepada mereka hartanya. (An-Nisa'/4: 6).

Ayat di atas menegaskan bahwa seorang perempuan memiliki hak menikah diusia matang, dijelaskan bahwa dia hanya bisa menikah ketika dia sudah cukup umur untuk menikah. Atau dengan bahasa lain, pernikahan seseorang boleh dilakukan ketika dia dewasa. Di ayat ini ditegaskan kalimat "sampai mereka mencapai usia menikah" yang menunjukkan bahwa setiap orang memiliki batas kematangan dalam menjalani pernikahan. Kematangan itu merupakan tanda dari berakhirnya masa anak-anak, dalam artian dia sudah harus memasuki usia dewasa. Karena itu, susunan ayat di atas merupakan isyarat yang cukup kuat mengenai ketentuan standar kelayakan seseorang untuk menjalani keluarga melalui pernikahan. Kesimpulan ini mengacu pada dua poin: 1) Ayat tersebut dengan tegas menyebut "sampai mereka mencapai usia nikah"; dan 2) Ayat menyebut kata Rusyd atau kecakapan. Berdasarkan penafsiran yang disampaikan al-Alusi di atas, kecakapan yang dimaksud tidak hanya menyangkut urusan duniawi namun juga ukhrawi. Dalam sebuah hubungan perkawinan, seorang suami maupun istri memiliki tanggung jawab besar untuk memenuhi kebutuhan materi bagi kelangsungan hidup keluarga, lebih-lebih ketika anak hadir di tengah-tengah mereka. Suami istri juga bertanggung jawab untuk menjalani keluarga yang cakap dalam mempersiapkan urusan ukhrawi. Kecakapan dan kesiapan dalam mengatur urusan keluarga akan menghadirkan kehidupan rumah tangga yang sesuai dengan nilai-nilai maqashid Al-Qur'an.

Kedewasaan selalu dihubungkan dengan kematangan mental, kepribadian, pola pikir, dan prilaku sosial. Namun kedewasaan juga erat hubungannya dengan pertumbuhan fisik dan usia. Kedewasaan juga kadang dikaitkan dengan kondisi seksual seseorang walaupun kemampuan reproduksi manusia tidak selalu ditentukan oleh faktor usia. Kedewasaan merupakan perpaduan yang seimbang antarajiwa, raga, dan intelektual. Ukuran kedewasaan memang sangat relatif, tergantung dari perspektif mana melihatnya.

\footnotetext{
${ }^{21}$ Asghar Ali Engineer, Hak-hak Perempaun dalam Islam, 139.
} 


\section{Ahmad Chalabi}

Pernikahan di bawah umur tidak dianjurkan mengingat mereka dianggap belum memiliki kemampuan untuk mengelola harta (rusyd). Selain itu, mereka juga belum membutuhkan pernikahan. Mereka dikhawatirkan tidak mampu memenuhi kewajiban-kewajiban yang harus dipikul dalam sebagai suami istri terutama dalam pengelolaan keuangan rumah tangga.

Dengan demikian, dapat disimpulkan bahwa pernikahan baru bisa dilakukan ketika mencapai usia matang. Baik laki-laki maupun perempuan keduanya memiliki hak untuk menikah pada usia yang matang. Oleh karena itu, tidak boleh ada pemaksaan khususnya kepadaanak perempuan yang belum cukup umur untukmelakukan pernikahan. Berdasarkanisyarat Al-Qur'andan Hadis di atas perempuan memiliki hak menikah diusia yang matang.

\section{Hak Pelaksanaan Pernikahan sesuai Ketentuan Agama dan Negara}

Pernikahanan yang tidak tercatat oleh Negara dikenal dengan istilah "nikah di bawah tangan", yaitu diartikan dengan nikah yang tidak dicatatkan pada instansi terkait, tapi dilaksanakan menurut agama dan kepercayaan masing-masing. Sedangkan nikah sirri adalah nikah yang sembunyi-sembunyi tanpa diketahui oleh orang di lingkungan sekitar. Nikah semacam ini (sirri) jelas-jelas bertentangan dengan Hadits Nabi yang memerintahkan adanya walimah (perayaan pernikahan) sebagaimana sabda Nabi Muhammad Saw:

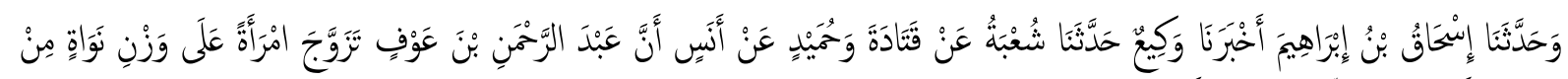

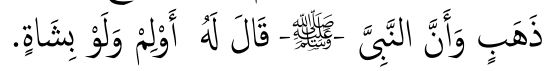

Telah menceritakan kepada kami Ishak bin Ibrahim telah mengabarkan kepada kami Waki' telah menceritakan kepada kami Syu'bah dariQatadah dari Humaidin dari Anas bahwaAbdurrahman menikahi seorang wanita dengan mahar Wazn Nawat dari emas dan kemudian Rasulullah Saw bersabda dan berkata kepadanya: "Adakanlah pesta perkawinan, sekalipun hanya dengan hidangan kambing”. (HR. Muslim). ${ }^{22}$

Keharusan pencatatan perkawinan di atas seharusnya dipahami sebagai bentuk baru dan resmi dari perintah Nabi Muhammad SAW agar mengumumkan atau menmgiklankan nikah meskipun dengan memotong seekor kambing. Dalam masyarakat kesukuan yang kecil dan tertutup seperti di Hijaz dahulu, dengan pesta memotong hewan memang sudah cukup sebagai pengumuan resmi. Akan tetapi dalam masyarakat yang kompleks dan penuh dengan formalitas seperti zaman sekarang ini, pesta dengan memotong seekor kambing saja tidak cukup melainkan harus didokumentasikan secara resmi pada kantor yang bertugas mengurusi hal itu. Karena itu mungkin kewajiban pencatatan ini dapat dipikirkan untuk menjadi tambahan rukun nikah dalam kitab fiqh baru nanti. Dengan demikian, apabila terjadi perselisihan atau pengingkaran telah terjadinya perkawinan, pembuktiannya cukup dengan alai bukti persaksian. Akan tetapi dalam perkembangan selanjutnya karena perubahan dan tuntutan zaman dan dengan pertimbangankemaslahatan, dibeberapa negara muslim,termasuk di Indonesia, telah dibuat aturan yang mengatur perkawinan dan pencatatannya.

\footnotetext{
${ }^{22}$ Imam Muslim, Shahih Muslim, Juz IV (Beirut: Dar al-Afaq al-Jadidah, 1334), 144.
} 
Melalui pencatatan perkawinan yang dibuktikan dengan akta nikah, apabila terjadi perselisihan di antara suami isteri, atau salah satu pihak tidak bertanggung jawab, maka yang lain dapat melakukan upaya hukum guna mempertahankan atau memperoleh haknya masing-masing, karena dengan akta nikah suami isteri memiliki bukti otentik atas perkawinan yang terjadi antara mereka. Berdasarkan penjelasan ini, yang paling banyak dirugikan dalam pernikahan di bawah tangan adalah pihak istri atau perempuan. Oleh karena itu, untuk menghindari dampak buruk tesebu .maka pihak perempuan memiliki hak untuk menikah sesuai dengan ketentuan agama dan negara.

\section{Hak Dimintakan Pendapat}

Hubungan suami dengan istri dalam rumah tangga tak akan lepas dari konteks komunikasi serta kesalingan dalam memutuskan banyak perkara. Untuk itu, aspek musyawarah_dalam rumah tangga juga perlu diperhatikan dengan baik. Dalam hal ini istri harus dilibatkan dalam mengabil keputusan dalam setiap masalah keluarga. Dengan kata lain istri berhak dimintakan pendapatnya serta persetujuannya dalam perkara kepentingan bersama dalam rumah tangga.

Muhammad Bagir dalam bukunya berjudul Muamalah Menurut Alquran, Sunah, dan Para Ulama menjelaskan, suami perlu menerapkan perilaku adil dalam bermusyawarah. Sehingga semua keputusan penting yang diambil olehnya sejauh mungkin tidak merupakan keputusan sepihak, melainkan keputusan yang diambil secara bersama-sama. ${ }^{23}$ Sikap harus bermuswarah dengan istri telah digariskan Allah dalam firman-Nya dalam Al-Quran surat As-Syura ayat 38:

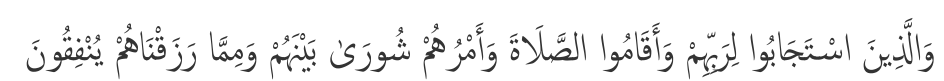

Dan (bagi) orang-orang yang menerima (mematuhi) seruan Tuhannya dan mendirikan shalat, sedang urusan mereka (diputuskan) dengan musyawarah antara mereka, dan mereka menafkahkan sebagian dari rezeki yang Kami berikan kepada mereka. (AsSyura/42: 38)

Secara lebih eksplisit dalam rumah tangga, sikap kesalingan antara suami dengan istri dianjurkan untuk saling tolong-menolong, termasuk dalam merumuskan mufakat dari musyawarah. Allah berfirman dalam Al-Quran surat At-Taubah ayat 71:

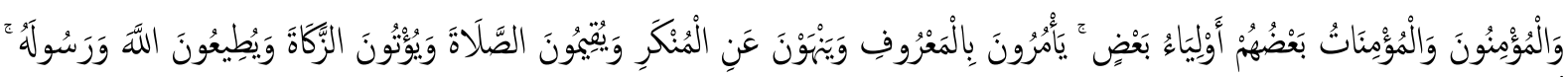

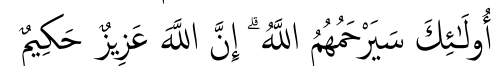

Dan orang-orang yang beriman, lelaki dan perempuan, sebagian mereka (adalah) menjadi penolong bagi sebagian yang lain. Mereka menyuruh (mengerjakan) yang makruf dan mencegah dari yang munkar, mendirikan shalat, menunaikan zakat, dan mereka taat kepada Allah dan Rasul-Nya. Mereka itu akan diberi rahmat oleh Allah, sesungguhnya Allah Mahaperkasa lagi Mahabijaksana. (At-Taubah/9: 71)

Muhammad Bagir berpendapat bahwa jelaslah mengenai musyawarah yang bukan aspek fundamental dalam tatanan sosial kenegaraan saja. Melainkan aspek

${ }^{23}$ Muhammad Bagir, Fiqih Praktis Panduan Lengkap Muamalah Menurut Al-Qur'an, Al-Sunnah, dan Pendapat Para Ulama (Jakarta: PT Mizan Publika, 2017), 33. 


\section{Ahmad Chalabi}

fundamental yang ada dalam tatanan rumah tangga. Musyawarah antara suami dengan istri harus dilakukan seiring dengan berlangsungnya rumah tangga yang hendak menjadi rumah tangga 'sehat'. ${ }^{24}$

Perbedaan pandangan antara suami dengan istri yang kerap terjadi tak lepas dari keputusan-keputusan sepihak yang dilakukan keduanya. Sehingga hal itu berkontribusi pada konflik rumah tangga yang berkepanjangan dan tak jarang justru bermuara pada perceraian yang dibenci Allah SWT, meskipun perceraian sendiri tak diharamkan dalam Islam. Namun demikian, mencegah perceraian dengan ikhtiarikhtiar yang ada dalam syariat agama merupakan kewajiban dan tanggung jawab yang harus diemban. Untuk itulah, aspek fundamental dari musyawarah di dalam rumah tangga sangatlah penting bagi umat Muslim seluruhnya.

\section{Hak Kesehatan Reproduksi}

Kesehatam reproduksi adalah kesehatan secara fisik, mental, dan kesejahteraan sosial secara utuh pada semua hal yang berhubungan dengan sistem dan fungsi, serta proses reproduksi dan bukan hanya kondisi yang bebas dari penyakit atau kecacatan. ${ }^{25}$ Alat Reproduksi perempuan adalah organ-organ yang berperan dalam serang kali proses yang bertujuan untuk berkembang biak atau memperbanyak keturunan. Agar manusia dapat memiliki anak, maka harus memiliki organ-organ reproduksi dengan fungsi dan dalam keadaan normal.Secara garis besar alat reproduksi perempuan terbagi kedalam dua kelompok, yaitu alat reproduksi (Genetalia) luar dan alat reproduksi (Genetalia) dalam.

Islam memberikan hak-hak reproduksi yang seimbang antara laki-laki dan perempuan. Berbeda dengan tradisi jahiliyah dikawasan Timur Tengah yang seolaholah menganggap reproduksi sebagai domain laki-laki. Dalam masyarakat jahiliyah perempuan dikonsepsikan sebagai the second creation yang harus diperlakukan sebagai the second sex. Mitologi perempuan pra Islam dikawasan ini mempersepsikan perempuan tidak layak menyejajarkan diri dengan laki-laki. Hakhak reproduksi adalah hak preogatif laki-laki dan menjadi kewajiban suci perempuan melayani hak-hak laki-laki tersebut. ${ }^{26}$

Keseimbangan hak-hak reproduksi laki-laki dan perempuan dapat dilihat dalam beberapa konsep hukum kekeluargaan diantaranya adalah sebagai berikut:

1) Menikmati Hubungan Seksual

2) Menentukan Menentukan Kehamilan

3) Menentukan Kelahiran

4) Mengasuh dan Mendidik Anak

\section{Hak Nafkah Lahir Batin dari Suami}

Hubungan perkawinan menimbulkan kewajiban nafkah atas suami untuk isteri dan anak-anaknya. Dalam hubungan ini Q.S. al-Baqarah: 233 mengajarkan bahwa suami yang telah menjadi ayah berkewajiban memberi

\footnotetext{
${ }^{24}$ Muhammad Bagir, Fiqih Praktis Panduan Lengkap Muamalah Menurut Al-Qur'an, Al-Sunnah, dan Pendapat Para Ulama, hal. 34.

${ }^{25}$ Eny Kusmiran, Kesehatan Reproduksi Remaja dan Wanita, Jakarta: Salemba Medika, 2012, hal. 94.

${ }^{26}$ Nasaruddin Umar, Teologi Reproduksi dalam Sri Suhandjati Sukri, ed, Bias Jender Dalam Pemahaman Islam, hal. 26
}

91 | al-§urhan: Kajian Ilmu dan Pengembangan Budaya Al-Qur'an, Vol. 20, No. 1, Juni 2020: 80-97. 
nafkah kepada ibu anak-anak (isteri yang telah menjadi ibu) dengan cara ma'ru>f. ${ }^{27}$ Itulah sebabnya Mah\}mud Yunus menandaskan bahwa suami wajib memberinafkah untuk isterinya dan anak-anaknya, baik isterinya itu kayaatau miskin, maupun muslim atau Nasrani/Yahudi. ${ }^{28}$ Bahkan kaum muslimin sepakat bahwa perkawinan merupakan salah satu sebab yang mewajibkan pemberian nafkah, seperti halnya dengan kekerabatan. ${ }^{29}$ Dengan demikian, hukum membayar nafkah untuk isteri, baik dalam bentuk perbelanjaan, pakaian adalah wajib. Kewajiban itu bukan disebabkan oleh karena isteri membutuhkannya bagi kehidupan rumah tangga, tetapi kewajiban yang timbul dengan sendirinya tanpa melihat keadaan isteri. Bahkan di antara ulama Syi'ah menetapkan bahwa meskipun isteri orang kaya dan tidak memerlukan bantuan dari suami, namun suami tetap wajib membayar nafkah.

Kewajiban suami memberi nafkah memiliki landasan hukum sebagai berikut: Di antara ayat Al-Qur'an yang menyatakan kewajiban perbelanjaan terdapat dalam surat al-Baqarah (2) ayat 233:

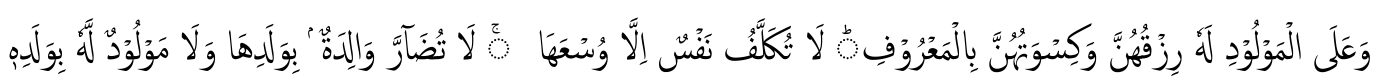

Kewajiban ayah untuk memberikan belanja dan pakaian untuk isterinya. Seseorang tidak dibebani kecuali semampunya, seorang ibu tidak akan mendapat kesusahan karena anaknya, dan seorang ayah tidak akan mendapat kesusahan karena anaknya. (Al-Baqarah/2: 233)

Tema sentral surat Al-Baqarah ayat 233 di atas adalah masalah penyususan anak. Adapaun kaitannya dengan kewajiban suami terhadap istri yang berupa nafkah adalah dalam menyusui anak tentunya seorang ibu membutuhkan biaya. Biaya inilah yang menjadi kewajiban suami. Suami berkewajiban memberikan makan dan pakaian kepada para ibu. Ayat di atas merupakan perintah, namun dengan redaksi berita (al-Amru bishighah al-khabar) bentuk redaksi kalimat seperti ini bertujuan untuk menguatkan (li al-Mubalaghah). Kewajiban memberikan nafkah kepada keluarga merupakan kewajiban atas dasar suami adalah kepala keluarga. Inilah yang diisyaratkan oleh rizquhunna wa kiswatuhunna menurut ayat di atas. Kata rizqu dalam ayat ini berarti biaya atau nafkah. Dalam Tafsir Jalalain dan tafsir al-Baghawi kata ini diartikan sebagai makanan. Sedangkan kata kiswah merupakan sinonim (murodhif) dari kata libas berarti pakaian, demikian jugapendapat al-Baghawi.

Jadi dapat dikatakan ayat di atas juga mengisyaratkan kewajiban memberikan biaya penyusuan. Biaya penyusan ini menjadi kewaibannya karena anak membawa nama bapaknya, seakan-akan anak lahir untuknya, karena nama ayah akan disandang oleh sang anak, yakni dinisbahkan kepada ayahnya. Kewajiban memberi makan dan pakaian itu hendaknya dilaksanakan dengan cara yang ma'ruf, yakni dengan dijelaskan maknanya dengan penggalan ayat berikutnya "seseorang tidak dibebani melainkan menurut kadar kesanggupannya. Janganlah seorang ibu menderita kesengsaraan karena anaknya" yakni jangan

\footnotetext{
${ }^{27}$ Ah\}mad Azhar Basyīr, Hukum Perkawinan Islam (Yogyakarta: UII Pers, 1999), 108.

${ }^{28}$ Mah\}mud Yūnus, Hukum Perkawinan dalam Islam (Jakarta: PT Hidakarya Agung, 1990), 101.

${ }^{29}$ Muhammad Jawad Mugniyah, al-Fiqh 'Alā al-Maz|āhlib al-Khamsah, Terj. Masykur, Afif Muhłammad, Idrus al-Kāff, "Fiqih Lima Mazhab" (Jakarta: Lentera, 2001), 400.
} 


\section{Ahmad Chalabi}

sampai ayah mengurangi hak yang wajar bagi seorang ibu dalam pemberian nafkah dan penyediaan pakaian, karena mengandalkan kasih sayang seoarng ibu kepada anaknya. Dan juga seorang ayah jangan sampai menderita karena ibu anak-anaknya menuntut sesuatu di atas kemampuan sang ayah, dengan dalih kebutuhan anak yang disusukannya.

\section{Hak dalam Memutuskan Perkawinan (Talak/Cerai)}

Perempuan sebagaimana laki-laki, mempunyai hak untuk menjatuhkan talak yang disebut khulu'. ${ }^{30}$ Pemutus akad nikah dari pihak Istri, Islam memberi peluang, jika Istri yang dirugikan secara syara' maka dapat mengajukan khulu' atau gugat cerai di pengadilan. Istri membayar kembali mahar/maskawin suaminya. Jika pengadilan menerima gugat cerai tersebut, maka putuslah ikatan nikahnya. Akibatnya, tidak bisa rujuk lagi..$^{31}$

Dalam hak talak bagi perempuan, Wahbah al-Zuhaili berpendapat bahwa seorang perempuan berhak mengajukan talak dengan alasan-alasan suami tidak dapat memberi nafkah dengan tidak mencukupi kebutuhan pangan, sandaang, dan papn serta kesehatan yang diperlukan oleh istri karena sebab cacat atau keadaan yang membuat dia tidak mampu menafkahi istri. Jika suami menolak, maka pengadilan yang akan memutuskannya, suami perperilaku kasar terhadap istri, kepergian suami yang relative lama,dan jika suami dalam status kurungan/tahanan. ${ }^{32}$ Sebagaimana yang telah diugkapkan di atas bahwa jika suami menolak permintaan talak dari istri maka istri dapat mengajukan cerai kepada pengadilan yang disebut dengan cerai gugat.

Hasil penafsiran terkait perkara khulu' meliputi hak khulu' kepada isteri dalam Al-Qur'an konsep khulu' memberikan solusi pada istri untuk menempatkan perceraian yang dilakukan dengan membayar tebusan dalam keadaan tertentu misalnya ketika seorang isteri atau suami dikhawatirkan akan melampui batas dengan melanggar hukum-hukum Allah jika pernikahan dilanjutkan. Misalnya dalam hal komunikasi yang baik atau keharmonisan. ${ }^{33}$ Kebebasan beribadah, pemenuhan hak dan kewajiban masing-masing. ${ }^{34}$ Apalagi jika suami bersifat dzalim kepada isterinya, maka khulu' inilah sangat dianjurkan sebagai solusi akhir. Larangan bagi mereka mengambil barang dari isteri mereka dalam kemadharatan atau kesulitan. Khulu' paling tidak dibenarkan kecuali apabila kesulitan tersebut tidak hanya dialami oleh sang suami. Kondisi ketika isteri diperbolehkan meminta khulu' menurut imam al-Qurthubi. Bahwa jika keduanya menginginkan bercerai, dimana keduanya saling membangkang sudah tidak mencapai rasa kasih sayang dan berperilaku sudah tidak ada sikap saling menghargai. ${ }^{35}$ Haram seorang isteri diperbolehkan mengajukan khulu' dengan menyerahkan mahar yang telah diberikan suami.

\footnotetext{
${ }^{30}$ Nasarudin Umar, Fikih Wanita untuk Semua (Jakarta: Serambi 2010), 121.

${ }^{31}$ Nasarudi Umar, Fikih Wanita Untuk Semua, 122.

${ }^{2}$ Mufidah. Ch. M.Ag, Psikologi Keluarga Islam berwawasan gender (Malang: UIN-MALANG

${ }^{33}$ Syeikh Abdul Halim Hasan Binjai, Tafsir Ahkam (Jakarta: Kencana, 2006), 118.

${ }^{34}$ Imam Syfi'ie, Hukum Al-Qur'an (As-Syafi'ie dan Ijtihadnya) Terj. Baihaqi Safi'uddin (Surabaya: Bangkul Indah, 1994), 205.

${ }^{35}$ Syeikh Imam Al-Qurthubi, Tafsir Al-Qurthubi, Jilid 3 (Jakarta: Pustaka Azam, 200o), 276.
} PRESS, 2008), 24. 
Menurut jumhur ulama Tafsir, khulu' didasarkan pada Al-Qur'an surat AlBaqarah ayat 229. Allah SWT berfirman:

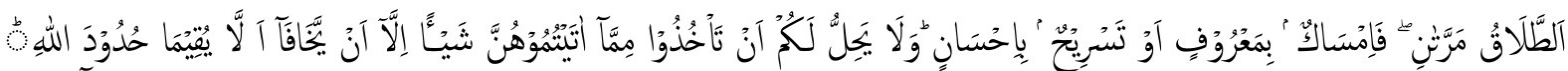

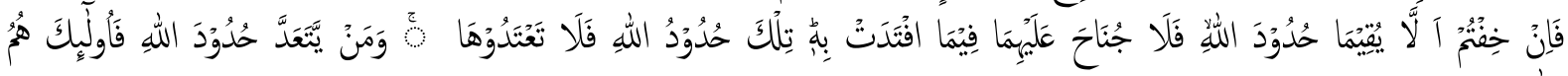
الظّالمِوُنَنَ

Talak (yang dapat dirujuk) itu dua kali. (Setelah itu suami dapat) menahan dengan baik, atau melepaskan dengan baik. Tidak halal bagi kamu mengambil kembali sesuatu yang telah kamu berikan kepada mereka, kecuali keduanya (suami dan istri) khawatir tidak mampu menjalankan hukum-hukum Allah. Jika kamu (wali) khawatir bahwa keduanya tidak mampu menjalankan hukumhukum Allah, maka keduanya tidak berdosa atas bayaran yang (harus) diberikan (oleh istri) untuk menebus dirinya. Itulah hukum-hukum Allah, maka janganlah kamu melanggarnya. Barangsiapa melanggar hukum-hukum Allah, mereka itulah orang-orang zhalim. (Al-Baqarah/2: 229)

Ayat ini menunjukan bahwa khulu' boleh dilakukan bukan hanya dalam keadaan takut dalam ayat $\mathrm{di}$ atas dimaksudkan bukan sebagai syarat, tetapi menunjukan situasi perempuan tersebut. Seperti situasi dimana hubungan suamiistri betul-betul tidak harmonis satu dengan yang lainnya sehingga khawatir tidak dapat melaksanakan hak-hak yang telah ditetapkan oleh Allah. ${ }^{36}$

8. Hak Waris Sebagai Anak, Istri dan Ibu

Dasar hukum waris dalam Al-Quran tertuang dalam surat al-Nisa ayat 7, 11, 12, 33, dan 176 sebagai berikut:

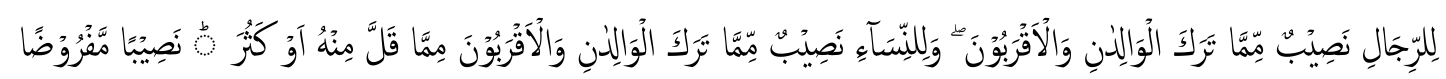

Bagi orang laki-laki ada hak bagian dari harta peninggalan ibu-bapak dan kerabatnya, dan bagi orang wanita ada hak bagian (pula) dari harta peninggalan ibu-bapak dan kerabatnya, baik sedikit atau banyak menurut bahagian yang telah ditetapkan. (al-Nisa/4 :7)

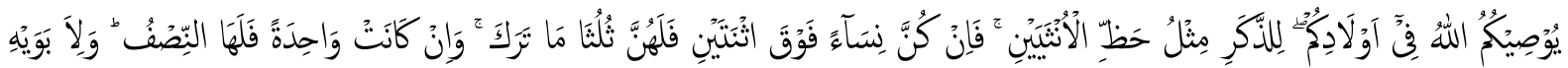

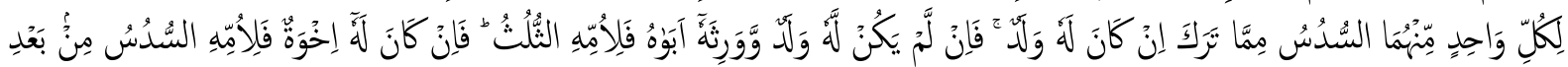

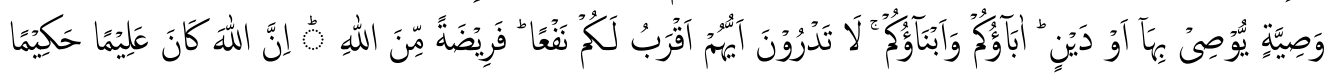
Allah mensyariatkan bagimu tentang (pembagian pusaka untuk) anakanakmu. Yaitu : bahagian seorang anak lelaki sama dengan bagahian dua orang anak perempuan; dan jika anak itu semuanya perempuan lebih dari dua, maka bagi mereka dua pertiga dari har ta yang ditinggalkan; jika anak perempuan itu seorang saja, Maka ia memperoleh separo harta. dan untuk dua orang ibu-bapak, bagi masing-masingnya seperenam dari harta yang ditinggalkan, jika yang meninggal itu mempunyai anak; jika orang yang meninggal tidak mempunyai anak dan ia diwarisi oleh ibu bapaknya (saja), Maka ibunya mendapat sepertiga; jika yang

\footnotetext{
${ }^{36}$ Nasaruddin Umar, Fikih Wanita Untuk Semua, 123.
} 


\section{Ahmad Chalabi}

meninggal itu mempu-nyai beberapa saudara, Maka ibunya mendapat seperenam. (Pembagian-pembagian tersebut di atas) sesudah dipenuhi wasiat yang ia buat atau (dan) sesudah dibayar hutangnya. (Tentang) orang tuamu dan anakanakmu, kamu tidak mengetahui siapa di antara mereka yang lebih dekat (banyak) manfaatnya bagimu. ini adalah ketetapan dari Allah. Sesungguhnya Allah Maha mengetahui lagi Maha Bijaksana. (Al-Nisa/4: 11)

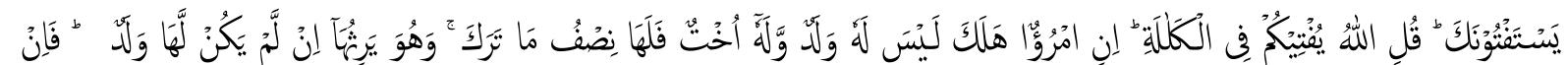

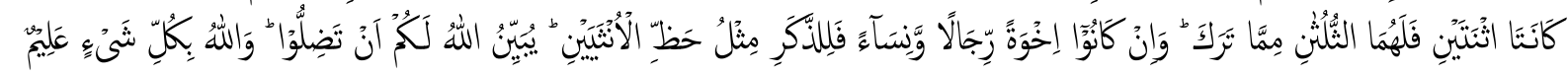
Mereka meminta fatwa kepadamu (tentang kalalah). Katakanlah: "Allah memberi fatwa kepadamu tentang kalalah (yaitu): jika seorang meninggal dunia, dan ia tidak mempu-nyai anak dan mempunyai saudara perem-puan, Maka bagi saudaranya yang perempuan itu seperdua dari harta yang ditinggal-kannya, dan saudaranya yang laki-laki mempusakai (seluruh harta saudara perempuan), jika ia tidak mempunyai anak; tetapi jika saudara perempuan itu dua orang, Maka bagi keduanya dua pertiga dari harta yang ditinggalkan oleh yang meninggal. dan jika mereka (ahli waris itu terdiri dari) saudara-saudara laki dan perempuan, Maka bahagian seorangsaudara laki-laki sebanyak bahagian dua orang saudara perempuan. Allah menerangkan (hukum ini) kepadamu, supayakamu tidak sesat. dan Allah Maha mengetahui segala sesuatu." ( Al-Nisa/4: 176)

Asbab al-Nuzul ayat-ayat tersebut adalah pada masa jahiliyah, dalam tradisi pembagian harta pusaka yang diwarisi oleh leluhur mereka terdapat suatu ketentuan utama bahwa anak-anak yang belum dewasadan kaum perempuan dilarang mempusakai harta peninggalan ahli warisnya yang telah meninggal dunia. Tradisi menganggap bahwa anak-anak yang belum dewasa dan kaum perem-puan adalah sebagai keluarga yang belum dan tidak pantas menjadi ahli waris. ${ }^{37}$ Bahkan menurut mereka janda perempuan dari orang yang meninggal merupakan harta peninggalan yang dapat dipusakakan dan dipusakai kepada dan oleh ahli waris yang meninggal.

Pandangan ini bahkan masih diikuti oleh orang-orang yang telah masuk Islam sekalipun, sampai suatu saat ada yang mengadukan persoalan mereka kepada Rasulullah Saw. seperti yang dilakukan oleh janda Sa'ad ibnu al-Rabbi'. Dia mengeluhkan kepada Rasulullah bahwa dua anak perempuan Sa'ad sama sekali tidak mendapatkan warisan dari harta peninggalan bapak mereka. Saudara lakilaki Sa'ad mengambil harta peninggalan Sa'ad tanpa tersisa sedikitpun untuk kedua anak perempuannya, padahal mereka sangat membutuhkan harta tersebut untuk biaya pernikahan. Pada saat itu Nabi berpesan ke-padanya agar dia kembali sambil mengatakan bahwa Allah akan memutuskan masalah ini. Beberapa waktu kemudian dia datang lagi untuk mengeluhkan hal yang sama. Pada saat itulah ayat-ayat ini diturunkan. Nabi memerintahkan saudara Sa'ad memberikan 2/3 kekayaannya untuk anaknya dan $1 / 8$ kepada ibunya, dan dia mendapatkan sisanya. ${ }^{38}$

Dengan demikian, dilihat dari konteks ini menjadi jelas bahwa al-Quran menjamin perempuan mendapatkan haknya sebagai seorang anak, isteri dan ibu.

\footnotetext{
${ }^{37}$ Muhammad Husain al-Thabathaba'i, al-Mīzān fì tafsīr Al-Qur'an, 132.

${ }^{38}$ Fakhruddin al-Rāzi, Tafsīr al-Kabīr (Beirut: Dār al-fikr. t.th), 210.
} 
Hanya saja, yang kemudian jadi persoalan adalah kasus pembagian warisan antara laki-laki dan perempuan yang tidak sebanding yang dipandang oleh sebagian kalangan tidak memenuhi rasa keadilan.

\section{Kesimpulan}

Setelah memaparkan mengenai beragam penjelasan dan analisis terhadap hak asasi perempuan dalam hukum keluarga berbasis Al-Qur'an, maka peneliti sampai pada kesimpulan yang merupakan jawaban dari rumusan masalah yang peneliti ajukan. Pertanyaan yang diajukan dalam rumusan masalah tersebut, yaitu: Bagaimana kedudukan perempuan dalam hak asasi perempuan? Bagaimana isyarat $\mathrm{Al}$ Quran tentang hak asasi perempuan dalam hukum keluarga? Dan bagaimana rumusan hak-hak perempuan dalam perspektif Al-Qur'an? Al-Qur'an begitu memuliakan perempuan dengan melihatnya sebagai mahluk yang utuh, dengan martabat agung dengan dimensi yang tak terhingga, dengan perempuan tidak dinilai dari segi keindahan tubuhnya kemolekan parasnya, kesupelan pergaulannya. Jauh lebih luas dari itu, perempuan dalam Islam juga dilihat sebagai manusia yang sama dengan laki-laki, punya tugas-tugas kemanusiaan, tanggung jawab pribadi dan sosial. Mereka punya otak untuk berfikir, nurani untuk mengambil keputusan, tangan untuk bekerja dan berkarya dan seterusnya. Semua potensi kemanusiaan yang diberikan kepada laki-laki juga diberikan kepada perempuan. Karenanya tidak ada perbedaan hak-hak mereka di bidang pendidikan, sosial dan lain-lainnya dalam Al-Quran. Kalaupun ada perbedaan itu adalah akibat fungsi dan tugas-tugas utama yang dibebankan agama kepada masing-masing jenis kelamin yang mengakibatkan suatu sama lainnya saling bantu membantu dan saling melengkapi dalam hidup dan kehidupan.

Al-Qur'an telah memberikan gambaran terperinci tentang hak asasi perempuan di seluruh sisi kehidupannya. Hak-hak perempuan yang banyak dibahas dalam Al-Qur'an adalah hak asasi perempuan dalam hukumkeluarga antara lain: Pertama, hak pendidikan. Dalam hal pendidikan perempuan diberikan hak untuk mendapatkan akses pendidikan dan juga diberikan hak untuk mendapatkan kesempatan prestasi. Kedua, hak dapat berperan dalam lingkup publik dan domestik. Pada bagian ini perempuan diberikan hak untuk bekerja, hak menjadi pemimpin dan berwirausaha.Ketiga, hak dalam perkawinan. Dalam hal ini diberikan hak menikah dengan keinginan sendiri, hak menikah di usia matang, hak pelaksanaan pernikahan sesuai ketentuan agama dan negara, hak kesehatan reproduksi, hak nafkah lahir batin dari suami dan hak khulu'. Keempat, hak waris. Pada masalah waris perempuan mendapatkan hak waris sebagai anak,hak waris sebagai istridan hak waris sebagai ibu. Kendati Al-Qur'an telah menjelaskan hak asasi perempuan dalam hukum keluarga, namun sayang pada tataran empiris pencapaian akan hal tersebut belum menunjukkan kemajuan yang signifikan. Sampai saat iniantara perempuan dan lakilaki masih terjadi kesenjangan dalam pemenuhan hak-haknya.Situasi ini dilatarioleh akar budaya masyarakat yang masih kental dengan budaya patriarki.Pada konteks budaya semacam ini dominasi laki-laki atas berbagaiperan di masyarakat dandi ranah publik tidak terelakkan. 


\section{DAFTAR PUSTAKA}

'Aisyiyah, PP. dan Majelis Tarjih dan Tajdid Pimpinan Pusat Muhammadiyah, Tuntunan Menuju Keluarga Sakinah. Yogyakarta: Suara Muhammadiyah, 2017.

Al-Rāzi, Fakhruddin. Tafsìr al-Kabìr, Beirut: Dār al-fikr. t.th.

Bagir, Muhammad. Fiqih Praktis Panduan Lengkap Muamalah Menurut Al-Qur'an, Al-

Sunnah, dan Pendapat Para Ulama. Jakarta: PT Mizan Publika, 2017.

Binjai, Syeikh Abdul Halim Hasan. Tafsir Ahkam. Jakarta: Kencana, 2006.

Basyīr, Ahmad Azhar. Hukum Perkawinan Islam. Yogyakarta: UII Pers, 1999.

Ch., Mufidah. Psikologi Keluarga Islam berwawasan gender. Malang: UIN-MALANG PRESS, 2008.

Eddiyono, Sriwiyanti. Bahan Bacaan Kursus HAM dan Materi Konvensi CEDAW. Jakarta: Lembaga Pengembangan dan Advokasi Masyarakat, 2005.

Engineer, Asghar Ali. Hak-hak Perempaun dalam Islam, terj. Farid Wajidi. Bandung, LSPPA, 1994.

Fakih, Mansour. Analisis Gender dan Transformasi Sosial, Cet. 9. Yogyakarta: Pustaka Pelajar, 2005.

Hasyim, Syafiq. Pengantar Feminisme dan Fundamentalisme Islam. Yogyakarta : LkiS, 2005.

Kelompok Kerja Convention Watch, Hak Azasi Perempuan: Instrumen Hukum untuk Mewujudkan Keadilan Gender, Jakarta: Yayasan Obor Indonesia, 2007.

Kusmiran, Eny. Kesehatan Reproduksi Remaja dan Wanita. Jakarta: Salemba Medika, 2012.

Luhulima, Achie Sudiarti. CEDAW: Menegakkan Hak Asasi Perempuan. Jakarta: Yayasan Pustaka Obor Indonesia, 2014.

Milton, J. (ed.) Hans Wehr:A Dictionary of Modern Written Arabic. Weibaden: Otto Harrassowitz, 1979.

Mugniyah, Muhammad Jawad. al-Fiqh 'Alā al-Maz|āhib al-Khamsah, Terj. Masykur, Afif Muhammad, Idrus al-Kāff, "Fiqih Lima Mazhab". Jakarta: Lentera, 2001.

Muslim, Imam. Shahih Muslim, Juz IV. Beirut: Dar al-Afaq al-Jadidah, 1334.

Omas, Ihromi et.al,. Penghapusan Diskriminasi Terhadap Perempuan, Bandung: PT Alumni, 2006.

Poerwadarminta, W.J.S. Kamus Umum Bahasa Indonesia. Jakarta: Balai Pustaka, 1982.

Subhan, Zaitunah. Qodrat Perempuan Taqdir Atau Mitos. Yogyakarta: Pustaka Pesantren, 2004.

Syfi'ie, Imam. Hukum Al-Qur'an (As-Syafi'ie dan Ijtihadnya) Terj. Baihaqi Safi'uddin. Surabaya: Bangkul Indah, 1994.

Ubayd, Dalal Kadzim. 'Mafhum Hurriyat al-Mar'ah fi Dlaw al-Fikr al-Tarbawial-Islami, Beirut: Kitab-Nashirun, 2011.

Umar, Nasarudin. Fikih Wanita untuk Semua, Jakarta: Serambi 2010.

Yūnus, Mahmud. Hukum Perkawinan dalam Islam. Jakarta: PT Hidakarya Agung, 1990.

Partners for Law in Development (PLD), CEDAW; Mengembalikan Hak-hak Perempuan, di terj. dan disunting oleh: Achie S. Luhulima, Jakarta: Juni, 2007.

Syeikh Imam Al-Qurthubi, Tafsir Al-Qurthubi, Jakarta: Pustaka Azam.

Vicky J. Semler et.al,. Hak Asasi Perempuan, Sebuah Panduan Konvensi-konvensi Utama PBB tentang Hak Asasi \{Perempuan, terj. Embun. Jakarta: Yayasan Jurnal Perempuan, 2001. 